\title{
PERTANGGUNGJAWABAN INDIVIDU ATAS GANTI RUGI DISGORGEMENT YANG MELIBATKAN EMITEN
}

\author{
Nikmah Mentari \\ Central for Local Law Development Studies (CLDS) FH UII, Yogyakarta \\ Vladimir Basyar Firnanda (VBF) Attorney at Law, Jakarta \\ nikmahmentari4@gmail.com_
}

\begin{abstract}
The Financial Services Authority (OJK) launched a discourse by issuing an RPOJK regarding the Disgorgement and Disgorgement Fund. The parties that can be subject to disgorgement are the perpetrators of the violations themselves, including the Issuer as a public limited liability company. However, if the Issuer commits a violation, it is reasonable for the order to be addressed to the in persona (private individual), considering the Issuer is an artificial person who has no will and cannot have a will without the party carrying out behind the scenes. Directors, Commissioners and major shareholders (controllers) are parties who are allowed to commit violations and at the same time enjoy illegal profits from the violation. However, affiliated parties may commit violations involving the Issuer, so if there is an illegal profit, those who enjoy the benefit should be obliged to compensate the disgorgement. The issuer as a public limited liability company has also received administrative sanctions by both the OJK and the stock exchange. It is very unfair for the Issuer to be responsible for paying disgorgement compensation.
\end{abstract}

Key words: responsibility, disgorgement, issuers, violations, capital market

\begin{abstract}
Abstrak
Otoritas Jasa Keuangan (OJK) meluncurkan wacana dengan mengeluarkan RPOJK tentang Disgorgement dan Disgorgement Fund. Para pihak yang dapat dikenakan disgorgement adalah pelaku pelanggaran itu sendiri, termasuk Emiten selaku perseroan terbatas terbuka. Akan tetapi, apabila Emiten melakukan pelanggaran, sewajarnya perintah tersebut ditujukan pada pelaku in persona (individu pribadi), mengingat Emiten sebagai artificial person yang tidak memiliki kehendak dan tidak dapat berkehendak tanpa pihak yang menjalankan di balik layar. Direksi, Komisaris dan pemegang saham utama (pengendali) merupakan pihak yang mungkin melakukan pelanggaran sekaligus menikmati keuntungan ilegal dari pelanggaran tersebut. Namun, pihak terafiliasi mungkin melakukan pelanggaran yang melibatkan Emiten, sehingga apabila terdapat keuntugan ilegal, seharusnya yang menikmati keuntungan tersebut yang diwajibkan mengganti rugi disgorgement. Emiten sebagai perseroan terbatas terbuka juga telah menerima sanksi administratif baik oleh OJK maupun bursa efek. Sangat tidak adil bagi Emiten bila harus bertanggung jawab membayar ganti rugi disgorgement.
\end{abstract}

Kata Kunci: tanggung jawab, disgorgement, emiten, pelanggaran, pasar modal 


\section{Latar Belakang}

Pasar Modal merupakan tempat berkumpulnya dana masyarakat (publik) yang menekankan 'kepercayaan' terhadap kegiatan di dalamnya. Kegiatan yang dimaksud yakni yang bersangkutan dengan Penawaran Umum dan perdagangan Efek, Perusahaan Publik yang berkaitan dengan Efek yang diterbitkannya, serta lembaga dan profesi yang berkaitan dengan Efek. ${ }^{1}$

Hubungan antara kepercayaan dan kegiatan di pasar modal terhadap masyarakat selaku investor sangatlah penting. Hal ini mengingat eksistensi pasar modal bergantung pada investor. Investor yang mempercayakan dananya untuk ditempatkan di pasar modal harus diberi perlindungan hukum sebagai bagian dari hak investor dan kewajiban stakeholder.

Kepercayaan tersebut salah satunya dibangun melalui keterbukaan informasi. Hal ini mengingat efek dianggap merupakan instrumen yang sifatnya sangat spekulatif sehingga sebenarnya secara inheren mengandung risiko. ${ }^{2}$ Adanya keterbukaan informasi yang harus dilakukan oleh perusahaan publik, investor akan dengan mudah memahami keadaan perusahaan secara umum, baik dari segi finansial maupun dari aspek-aspek lainnya, berdasarkan informasi yang disajikan perusahaan secara mutakhir dari waktu ke waktu. ${ }^{3}$
Emiten, selaku tempat investor menanamkan modalnya, diharapkan untuk selalu memberi keuntungan bagi investor. Oleh karena itu, kinerja perusahaan harus dikelola dengan manajemen yang baik. Manajemen yang dikelola tidak baik akan menimbulkan kerugian bagi perusahaan. Kerugian yang terjadi pada emiten akan menimbulkan kerugian pula bagi investor (domino effect). Hal ini merupakan suatu risiko bisnis, selain adanya keuntungan juga pasti terdapat kerugian. Kerugian yang wajar sebagai risiko bisnis dapat ditoleransi. Akan tetapi, kerugian akibat adanya pelanggaran merupakan suatu hal yang patut dimintai pertanggungjawaban secara hukum.

Pada Pasal 110 Undang-Undang Nomor 8 Tahun 1995 tentang Pasar Modal (UUPM), pelanggaran di bidang pasar modal terdiri dari dua jenis yakni tindak pidana berupa pelanggaran dan tindak pidana berupa kejahatan. Tindak pidana pelanggaran dikenakan sanksi administratif, sedangkan tindak pidana kejahatan dikenakan sanksi pidana. Kedua bentuk pelanggaran tersebut apabila merugikan investor secara langsung dari sisi materiil, tidak mengembalikan kerugian yang diderita investor. Adapun apabila investor hendak mendapatkan ganti kerugian harus mengajukan gugatan ganti rugi melalui pengadilan yang membutuhkan waktu, biaya, tenaga dan pikiran sehingga

1 Pasal 1 Angka 13 UU Pasar Modal.

2 Muhammad Hajoran Pulungan, "Penegakan Hukum dalam Prinsip Keterbukaan Informasi di Pasar Modal", Jurnal Ilmu Hukum STIH Litigasi Vol. 2, No. 1, (Februari 2018):54

3 Ibid. 
kurang efisien bagi investor. Hal ini akan menimbulkan 'krisis kepercayaan' investor terhadap investasi di pasar modal akibat tidak terpulihkannya kerugian yang ditanggung.

Menurut M. Nasarudin dkk, bahwa persoalan terjadinya kejahatan dan pelanggaran di pasar modal diasumsikan berdasarkan beberapa alasan yaitu kesalahan pelaku, kelemahan aparat yang mencakup integritas dan profesionalisme, dan kelemahan peraturan. Oleh sebab itu, otoritas pasar modal berkewajiban selalu melakukan penelaahan hukum yang menyangkut perlindungan hukum dan penegakan hukum yang semakin penting. ${ }^{4}$

Hal ini mengingat Lembaga Pasar Modal merupakan lembaga kepercayaan yaitu lembaga perantara (intermediary) yang menghubungkan kepentingan pemakai dana (issuer, ultimate borrower) dan para pemilik dana (pemodal, ultimate lender). ${ }^{5}$ Efektivitas hukum pasar modal untuk menstimulasi perkembangan pasar terletak pada beberapa faktor, ${ }^{6}$ yaitu: pembaharuan hukum pasar modal, dan perlindungan investor. Faktor yang berhubungan dengan penegakan hukum pasar modal, dan perlindungan investor. Faktor yang berhubungan dengan pembaharuan hukum menjadi kunci utama, karena pasar modal hanya dapat berkembang bila pasar dapat menawarkan produk baru yang murah dan efisien dalam bentuk efek-efek (saham atau obligasi). Pembaharuan hukum yang dimaksud adalah pembentukan hukum yang nyaman bagi pasar oleh otoritas pasar yang independen dan kuat. ${ }^{7}$ Dinamika pasar modal menuntut keberadaan regulator yang mampu memberikan keadaan. Pembaharuan hukum akan mendorong pasar kearah yang lebih kompetitif dan modern sehingga berbagai peluang investasi akan mendorong partisipasi investor yang lebih tinggi. ${ }^{8}$

Oleh karena itu, dalam menyambut pembaharuan hukum, Otoritas Jasa Keuangan (OJK) melalui kewenangannya menurut Pasal 6 hurufb ${ }^{9}$ jo Pasal 8 jo Pasal 9 UU Pasar Modal, berencana menerapkan regulasi baru bernama ganti rugi disgorgement dan disgorgement fund'. ${ }^{10}$ Regulasi tersebut dalam rangka meningkatkan perlindungan dan memberikan

4 M. Irsan Nasarudin, dkk, Aspek Hukum Pasar Modal Indonesia, Cetakan ke-7, (Jakarta: Kencana Prenada, 2011), hlm. 258-259.

5 Ibid.

6 Indra Safitri dalam Rochani Urip Salami, “ Hukum Pasar Modal dan Tanggung Jawab Sosial”, Jurnal Dinamika Hukum Vol.11, No.3, (September 2011): 441

7 Rochani Urip Salami, Ibid, hlm.441-442.

8 Ibid.

9 OJK melaksanakan tugas pengaturan dan pengawasan terhadap: ... b. kegiatan jasa keuangan di sektor Pasar Modal

10 Danang Sugianto, OJK akan Kumpulkan Uang Ganti Rugi dari 'Penjahat Bursa', https://finance.detik. com/bursa-dan-valas/d-4433294/ojk-akan-kumpulkan-uang-ganti-rugi-dari-penjahat-bursa diakses pada 28 februari 2019; Dwi Nicken Tari, OJK Wacanakan Pemberian Ganti Rugi Kepada Investor Akibat Tindak Pidana, https://market.bisnis.com/read/20190219/7/890532/ojk-wacanakan-pemberian-ganti-rugi-kepadainvestor-akibat-tindak-pidana- diakses 28 februari 2019; Monica Wareza, Investor Makin Tenang, OJK Godok Aturan Rugi Transaksi Saham, https://www.cnbcindonesia.com/market/20190218180420-17-56237/investormakin-tenang-ojk-godok-aturan-rugi-transaksi-saham diakses 28 Februari 2019;OJK Kaji Dana Ganti Rugi Investasi Bagi Masyarakat, https://www.cnnindonesia.com/ekonomi/20190218194501-78-370497/ojk-kajidana-ganti-rugi-investasi-bagi-masyarakat diakses 28 februari 2019. 
rasa 'aman' bagi investor di pasar modal, khususnya investor ritel. Pemberian ganti rugi berupa 'disgorgement' merupakan konsep yang melibatkan pelaku pelanggaran di bidang pasar modal untuk menyerahkan keuntungan ilegal yang diperoleh. Disgorgement sendiri merupakan konsep yang diadopsi dari lembaga Securities Exchange Commission $(\mathrm{SEC})^{11} \mathrm{di}$ Amerika Serikat.

Pada 18 Maret 2019 telah dikeluarkan Rancangan Peraturan Otoritas Jasa Keuangan (RPOJK) tentang Disgorgement dan Disgorgement Fund yang telah dimintakan tanggapan kepada para ahli dan masyarakat umum terhadap RPOJK tersebut hingga tanggal 29 Maret 2019.12 Oleh karena itu, terkait dengan adanya perintah membayar ganti rugi disgorgement haruslah ditetapkan sebagai tanggung jawab individu atau sekelompok orang yang menikmati keuntungan tersebut. Hal ini mengingat, apabila pelanggaran di pasar modal melibatkan emiten selaku perusahaan terbuka, patut dilakukan analisis mendalam. Sebagai sebuah badan hukum (rechts persoon), emiten tidak dapat bergerak sendiri untuk melakukan pelanggaran. Terlebih lagi menikmati keuntungan ilegal akibat pelanggaran tersebut. Hal ini berdasarkan pada posisi emiten yang juga tunduk pada Undang-Undang Perseroan Terbatas (UUPT) sehingga berlaku hukum perseroan. Dalam Emiten terdapat organ perseroan serta afiliasi yang merupakan orang (natuurlijke persoon) yang memiliki akal, pikiran dan kehendak. Oleh karena itu, organ perseroan dan setiap pihak yang terafiliasi lebih berpotensi untuk menggerakkan suatu Emiten melakukan pelanggaran dan menikmati keuntungan tersebut secara pribadi. Karena sejatinya ganti rugi disgorgement ialah pengembalian kerugian investor, maka perlu dikaji pihak yang bertanggung jawab untuk membayar ganti rugi disgorgement dengan melibatkan emiten sebagai perisai.

Penelitian ini menggunakan penelitian yuridis-normatif dengan pendekatan konseptual (conceptual approach) dan pendekatan perundang-undangan (statute approach). Pendekatan perundang-undangan (statue approach) dilakukan dengan menelaah dan mengkaji keseluruhan undang-undang dan regulasi yang saling terkait dengan isu hukum yang sedang diteliti. ${ }^{13}$ Pendekatan perundang-undangan dipergunakan untuk mempelajari konsistensi undang-undang dengan undang-undang dasar maupun peraturan perundang-undangan yang lain sekaligus menjawab isu hukum. ${ }^{14}$ Selain itu, pendekatan undang-undang (statute approach) sebagai pendekatan yang dilakukan

11 Lembaga otoritas pasar modal di Amerika Serikat seperti halnya OJK.

12 OJK, Permintaan Tanggapan Masyarakat atas RPOJK tentang Disgorgement dan Disgorgement Fund di Bidang Pasar Modal, https://www.ojk.go.id/id/regulasi/otoritas-jasa-keuangan/rancangan-regulasi/Pages/ Permintaan-Tanggapan-Masyarakat-atas-RPOJK-tentang--Disgorgement-dan-Disgorgement-Fund-diBidang-Pasar-Modal.aspx, diakses 28 februari 2019.

13 Peter Mahmud Marzuki, Penelitian Hukum, (Jakarta: Kencana Prenada Media, 2013), hlm.133.

14 Abdul Kadir Muhammad, Hukum dan Penelitian Hukum, (Bandung: Citra Aditya Bakti, 2004), hlm.52 
untuk meneliti aturan perundang-undangan, dan berbagai aturan hukum yang menjadi fokus penelitian. ${ }^{15}$ Pendekatan konseptual merupakan pendekatan yang beranjak dari pandangan-pandangan dan doktrin-doktrin yang berkembang dalam ilmu hukum. ${ }^{16}$

\section{PEMBAHASAN}

\section{A. Pengertian dan Perkembangan Ganti Rugi Disgorgement}

Amerika Serikat menerapkan disgorgement selama beberapa dekade sebagai alat yang signifikan dan bagian terpenting program penegakan di pasar modal bagi lembaga otoritas. ${ }^{17}$ Melalui undangundang sekitar tahun 1933 dan 1940, Kongres telah memberikan sebuah pendekatan lebih luas dan definitif terhadap investor melalui civil remedy-pemulihan secara perdata. $^{18}$ Pemulihan ini ditujukan kepada investor yang mengalami fraud (kecurangan) pembelian atau penjualan efek. ${ }^{19}$

Oleh karena itu, diaturlah Securities Exchange Act of 1934 (the Exchange Act) yang menghasilkan lembaga bernama Securities Exchange Commission (SEC). SEC diberikan jaminan otoritas oleh The Exchange Act secara luas dalam menegakkan hukum sekuritas federal dan mengadopsi berbagai aturan yang telah ada untuk melindungi para investor. ${ }^{20}$ The Exchange Act tidak mengatur tentang disgorgement maupun lembaga penghimpun hasil disgorgement yang kemudian disebut Fair Fund. Akan tetapi, the Exchange Act hanya mengatur kewenangan sebuah lembaga untuk menegakkan regulasi di bidang sekuritas. Hal ini menunjukkan bahwa awal mula konsep yang ditawarkan bukan serta merta konsep disgorgement, melainkan konsep dari penjabaran kewenangan otoritas pasar modal (SEC). ${ }^{21}$

Kewenangan SEC dalam menegakkan the Exchange Act dapat ditempuh dalam melalui berbagai langkah untuk melengkapi sanksi pidana (criminal penalties) dan tanggung jawab perdata (civil liabilities). ${ }^{22}$

Sanksi tersebut harus diluar konsep sanksi pidana maupun sanksi perdata. Jika 'fine' atau denda dikategorikan ke dalam sanksi pidana yang juga dapat dikategorikan sebagai sanksi perdata. Sedangkan, 'imprisonment' atau pemenjaraan juga telah masuk sanksi

\section{Ibid.}

16 Ibid, hlm.135.

17 Veronica E. et. all, "Limitation Period for SEC Enforcement Matters", The Hedgefund Journal,(April-May 2017), p.1.

18 Murray L. Simpson, “Investors' Civil Remedies Under The Federal Securities Laws", Depaul Law Review Vol.12, Issue I, Article 5, (1962): 71.

19 Ibid.

20 Jacqueline K. Chang, "Kokesh v. SEC:The Demise of Disgorgement," North Carolina Banking Institute, Vol.22, (2018), p. 309.

21 Nikmah Mentari, Pemberian Ganti Rugi Investor di Pasar Modal Melalui Disgorgement Fund, Tesis, Magister Ilmu Hukum, (Surabaya: Universitas Airlangga, 2019), hlm. 15-16.

22 John Hanna, “The Securities Exchange Act of 1934”, Carolina Law Review, Vol. XXIII, Number I, (November 1934),p. 22. 
pidana. Maka, kedua konsep tersebut tidak dapat digunakan lagi. Oleh karena itu, konsep remedy, yakni pemulihan digunakan. Dalam mewujudkan konsep remedy secara teknis, maka, salah satu diskresi berupa kewenangan yang disebut 'injunction'-perintah atau panggilan dari pengadilan. ${ }^{23}$

Kewenangan tersebut yakni pemberian perintah atau surat perintah (mandamus) untuk mencegah pelanggaran di pasar modal atau sebagai alat paksa dalam mematuhi Securities Act. $^{24}$ Hal inilah yang kemudian menjadi tonggak perjalanan pembayaran ganti rugi disgorgement di Amerika Serikat yang kemudian diikuti oleh negara-negara di dunia, termasuk di Indonesia.

Secara terminologi, Disgorgement is " [t] he act of giving up something (such as profits illegally obtained) on demand or by legal compulsion." ${ }^{25}$ menyerahkan keuntungan berdasarkan perintah atau paksaan hukum yang didapatkan secara ilegal. Disgorgement dimaknai sebagai perintah dari pihak berwenang yang bersifat memaksa atas akibat dari perbuatan yang merugikan. Bahkan apabila tidak dibayarkan dapat dilakukan 'upaya paksa' melalui pengadilan. ${ }^{26}$
Hal ini berarti bahwa tindakan tersebut termasuk sebagai tindakan represif bagi investor, ketika terjadi pelanggaran di pasar modal, maka pelaku pelanggaran dikenai kewajiban untuk mengembalikan ganti rugi ke investor. Disgorgement merupakan sebuah upaya dan cara bagi SEC untuk memperoleh uang demi memberi rasa adil bagi investor, seek equitable relief that may appropriate or necessary for the benefit of investor'27 maka usaha memberikan pemulihan dana sepatutnya dilakukan dengan 'memaksa' pelaku untuk membayar sejumlah kerugian yang diderita oleh investor. Secara konsep disgorgement diasumsikan sebagai 'an equitable remedy'28, sebuah pemulihan yang adil.

Terkait dengan disgorgement, Amerika Serikat memiliki lembaga 'Fair Funds'. ${ }^{29}$ Ketika SEC berhasil melakukan penegakan hukum terhadap pelanggaran di bidang sekuritas, pengadilan atau SEC dapat memerintahkan pelaku pelanggaran 'to disgorge (give up)'-menyerahkan ill-gotten gains. ${ }^{30}$ Maksud dari ill- gotten gains yaitu "are things that someone has obtained in dishonest or illegal way." 31 Sesuatu yang

23 Nikmah Mentari, Op.Cit, hlm.16.

24 John Hanna, Op.Cit. Lihat Securities Act Section 21.

25 Bryan A. Garner, Black Law's Dictionary, 8th edition, (Thomson Reuters, 2004), pp.1410-1411.

26 Nikmah Mentari, Op.Cit, hlm. 3.

27 Jacqueline K. Chang, Op.Cit, p. 311.

28 SEC v Quan, 817 F.3d 583.595 ( $8^{\text {th }}$ Cir.2016) dalam Jacqueline K. Chang, Ibid.

29 Rules of Practice and Rules on Fair Fund and Disgorgement Plans, United States Securities and Exchange Commission, June 2018.

30 Nikmah Mentari, Op.Cit, Lihat pula Investor Bulletin: How Victims of Securities Law Violations May Recover Money, https://www.sec.gov/oiea/investor-alerts-bulletins/ib_recovermoney.html diakses pada 11 April 2019.

31 Collins Dictionary English, ill-gotten gains https://www.collinsdictionary.com/dictionary/english/ill-gottengains diakses pada 11 Mei 2019. 
mana seseorang memperolehnya dengan cara tidak jujur/curang atau cara ilegal.

Indonesia, melalui OJK telah memunculkan wacana sejak tahun 2019 akan merilis regulasi terkait dengan sistem disgorgement dan lembaga disgorgement fund..$^{32}$ Secara teknis, pihak yang melakukan fraud/kecurangan akan dikenakan denda yang sanksinya dibayarkan pada investor yang dirugikan. ${ }^{33}$ Pada pasal 3 Ayat (1) UU Pasar Modal menegaskan bahwa pembinaan, pengaturan, dan pengawasan sehari-hari kegiatan pasar modal dilakukan oleh Badan Pengawas Pasar Modal yang selanjutnya disebut Bapepam (saat ini bernama OJK). Saat ini kewenangan Bapepam telah beralih ke OJK (Pasal 2 ayat (2) Undang-Undang Nomor 21 Tahun 2011 Tentang Otoritas Jasa Keuangan (UU OJK)). Bentuk perlindungan hukum yang dilakukan OJK terhadap investor diatur dalam UU OJK bersifat pencegahan atau preventif dan pemberian sanksi atau represif, mengingat bahwa tugas OJK adalah menjalankan fungsi pengaturan dan pengawasan sektor jasa keuangan. Selanjutnya, Pasal 28 UU OJK memberikan perlindungan hukum bersifat pencegahan kerugian konsumen dan masyarakat.

Meskipun masih berupa 'wacana', akan tetapi keseriusan OJK dalam memberikan perlindungan dan mengembalikan kepercayaan investor di pasar modal telah terlihat dengan adanya Rancangan Peraturan Otoritas Jasa Keuangan tentang Disgorgement dan Disgorgement Fund. Apabila dikaji lebih mendalam terkait dengan RPOJK tersebut, maka untuk sementara dapat dikaji 'arah dan bentuk' disgorgement yang akan diterapkan di Indonesia menurut versi OJK.

Menurut Pasal 1 Angka 3 RPOJK, menyebutkan pengertian disgorgement adalah bentuk upaya OJK memberi perintah kepada Pihak yang melakukan pelanggaran terhadap peraturan perundang-undangan di bidang Pasar Modal untuk mengembalikan uang sejumlah keuntungan yang diperoleh/ kerugian yang dihindari secara tidak sah/ melawan hukum.

Unsur-unsur disgorgement dari pasal tersebut yakni pertama, sebuah 'upaya OJK memberi perintah' yang mana salah satu 'cara atau alat melalui perintah tertulis' bagi OJK berdasarkan kewenangannya sebagai pengawas dan penegak hukum di pasar modal. ${ }^{34}$ Kedua, 'pihak yang melakukan pelanggaran' yang artinya pihak disini berlaku baik bagi perorangan, korporasi maupun kelompok. Ketiga, 'peraturan perundang-undangan di bidang pasar modal' yakni dimulai dari UU Pasar Modal beserta peraturan di bawahnya tentang pasar modal. ${ }^{35}$ Keempat, 'mengembalikan uang sejumlah'

32 Novita Sari Simamora, Regulasi Disgorgement dan Disgorgement Fund Bakal Rampung Tahun ini, https:// market.bisnis.com/read/20190329/7/906115/regulasi-disgorgement-disgorgment-fund-bakal-rampungtahun-ini diakses pada 1 April 2019

33 Ibid.

34 Nikmah Mentari, Op.Cit, hlm.29.

35 Ibid. 
artinya menyerahkan kembali uang dari pihak pelaku pelanggaran. Kelima, 'keuntungan yang diperoleh/kerugian yang dihindarkan secara tidak sah/melawan hukum', dari uang yang didapatkan melalui dua cara melawan hukum yaitu mendapatkan keuntungan atau menghindari kerugian. ${ }^{36}$ Serangkaian perbuatan padakelima unsur tersebut bermuara pada kerugian investor. Sehingga penting bagi pelaku pelanggaran untuk mengembalikan hak investor yang dirugikan.

Pada prinsipnya disgorgement merupakan upaya yang juga dimaksudkan untuk penegakan hukum yang disiplin bagi pelaku pelanggaran hukum pasar modal yang pada akhirnya dapat memberikan efek jera. Agar tidak ada pihak yang merasa dirugikan karena akibat dari pelanggaran dipasar modal yang terkadang tidak bisa dirasakan secara langsung. ${ }^{37}$ Hal ini menujukkan rencana pengaturan mekanisme disgorgement tidak sebatas perlindungan hukum investor terhadap kerugian yang dialaminya akibat pelanggaran di pasar modal. Akan tetapi, memiliki tujuan untuk keseimbangan dan menciptakan pasar yang sehat agar dapat memberikan perlindungan hukum, kepastian hukum serta meningkatkan kepercayaan investor dalam pasar modal Indonesia. ${ }^{38}$

Pasal 1 angka 9 RPOJK menyebutkan pengertian disgorgement fund adalah dana yang dihimpun dari pengenaan disgorgement kepada pihak yang melakukan pelanggaran terhadap peraturan perundang-undangan di bidang pasar modal dengan tujuan untuk diadministrasikan dan didistribusikan kepada pihak yang dirugikan atas pelanggaran terhadap peraturan perundang-undangan di bidang pasar modal, dan pihak yang dirugikan dimaksud telah mengajukan klaim dalam jangka waktu yang ditentukan. OJK akan menetapkan jumlah pencairan sebesarbesarnya keuntungan yang diperoleh secara ilegal atau kerugian yang dapat dihindari secara ilegal oleh pihak yang melakukan pelanggaran peraturan pasar modal ditambah dengan bunga pencairan (jika ada). ${ }^{39}$

Pasal 4 ayat (1) RPOJK menetapkan batas waktu pembayaran disgorgement kepada OJK paling lambat 30 hari setelah diterimanya penetapan disgorgement oleh pihak pelaku pelanggaran. Apabila tidak membayar dalam jangka waktu seperti pada ayat (1), pada ayat (3) dan ayat (4) memberikan surat teguran sebanyak dua kali untuk segera membayar perintah disgorgement beserta Bunga Penagihan Disgorgement dengan masingmasing waktu tunda 30 hari. Pada ayat (5) menegaskan jumlah Bunga Penagihan Disgorgement sebagaimana yang tertera pada ayat (1),(3),(4) ditetapkan sebesar 2\% perbulan dari jumlah disgorgement yang ditetapkan

36 Ibid.

37 Raysa Mayasonda, dkk, "Kajian Terhadap Rencana Pengaturan Disgorgement Dalam Pasar Modal Indonesia”, Jurnal Cendekia Hukum, Vol. 6, No. 1, (September 2020), hlm.8.

38 Ibid.

39 Uni Tsulasi Putri, "Disgorgement as Remedial Action in Indonesia Capital Market Regime", Jurnal Hukum Novelty Vol. 11, Issue 01, (2020): 4 
oleh OJK dan paling banyak 6\% dari jumlah Disgorgement yang ditetapkan OJK dengan ketentuan bagian dari bulan dihitung 1 (satu) bulan.

Menurut Direktorat Penetapan Sanksi dan Keberatan Pasar Modal OJK, Pengembalian Keuntungan Tidak Sah (Disgorgement) adalah perintah OJK untuk mengembalikan keuntungan yang diperoleh atau kerugian yang dihindari secara tidak sah oleh pihak yang melakukan dan/atau pihak yang menyebabkan terjadinya pelanggaran terhadap peraturan perundang-undangan di bidang pasar modal. ${ }^{40}$ Substansi Disgorgement adalah perintah untuk mengembalikan keuntungan atau kerugian yang dihindari secara tidak sah, bukan pada gugatan investor yang dirugikan. Oleh karena itu dianggap sebagai remedial action. ${ }^{41}$

Karena berupa pemulihan, maka sesungguhnya disgorgement menerapkan keadilan restoratif (restorative justice). Sistem keadilan restoratif mengutamakan pengembalian kerugian akibattindak kejahatan kepada korban, sehingga atas tindakan kejahatan tersebut menciptakan kewajiban untuk membenahi (restorasi) kerusakan atau kerugian akibat terjadinya suatu tindak pidana tersebut. ${ }^{42}$ Menurut Wright tujuan utama dari keadilan restoratif ialah pemulihan sedangkan tujuan keduanya yakni ganti rugi. ${ }^{43}$

Selain itu, disgorgement juga sebenarnya menerapkan keadilan korektif (corrective justice) yang diusung oleh Aristoteles. Keadilan korektif berupaya memberikan restitution kepada pihak yang dirugikan atau dengan kata lain mengembalikan pihak yang dirugikan ke keadaan semula sebelum timbulnya kerugian tersebut. ${ }^{44}$ Berdasarkan pengamatan Aristoteles bahwa kedudukan keuntungan dan kerugian adalah saling bertimbal balik. Apabila salah satu pihak memperoleh keuntungan maka di sisi lain, pihak yang lain akan menerima kerugian. ${ }^{45}$

Oleh karena itu, pengembalian keuntungan dilakukan oleh pihak yang menerima dan menikmati keuntungan itu sendiri. Ganti rugi disgorgement berbeda halnya dengan sanksi sebagai sebuah hukuman atau ganti rugi pada gugatan perdata. Disgorgement hanya mengembalikan kedudukan pelaku pelanggaran dan korban yakni investor sebelum adanya pelanggaran. Kedudukan tersebut berupa tidak ada keuntungan ilegal yang diterima pelaku, sekaligus tidak ada kerugian yang dialami investor.

40 Jawaban Tertulis Direktorat Penetapan Sanksi OJK dikutip dari Nikmah Mentari, Op.Cit, hlm.36.

41 Ibid.

42 TJ. Gunawan, Konsep Pemidanaan Berbasis Nilai Kerugian Ekonomi, Cetakan Pertama, (Yogyakarta: Genta, 2015), hlm.100.

43 Rufinus Hotmaulana, Penanggulangan Kejahatan Korporasi Melalui Pendekatan Restoratif Suatu Terobosan, dalam Sarwirini “Implementasi Restorative Justice Dalam Penegakan Hukum Pajak," Yuridika Vol. 29, No.3, (September-Desember 2014): 383.

44 Faisal Kurniawan, dkk, "Unsur Kerugian Dalam Unjustified Erinchment untuk Mewujudkan Keadilan Korektif (Corrective Justice)", Yuridika, Vol. 33, No.1, (Januari 2018): 23-24.

45 Ernest J. Weinrib, "Restitutionary Damages as Corrective Justice," Theoretical Inquiries in Law, Vol.1, (2001): 3 . 
Menurut RPOJK Disgorgement dan Disgorgement Fund, disgorgement secara teknis dijalankan dalam bentuk Perintah Tertulis (Pasal 1 Angka 1 jo Angka 4). Sebagai sebuah perintah yang terjadi karena adanya pelanggaran dan menimbulkan kerugian investor, maka harus dipenuhi secara serta merta terlepas tanpa menunggu proses penyidikan lebih lanjut. Hal ini merupakan suatu terobosan hukum baru di Indonesia karena perintah berupa disgorgement tidak pernah dikenal dalam sistem hukum Indonesia. Sebaliknya, di Amerika Serikat, disgorgement dapat ditegakkan melalui perintah SEC atau putusan pengadilan. ${ }^{46}$

Pengembaliangantikerugian disgorgement merupakan bentuk keberpihakan hukum dari aspek korban yang dirugikan. Dalam pasar modal, setiap adanya pelanggaran yang kemudian menimbulkan kerugian secara materiil, kerugian korban tidak dapat secara otomatis terpulihkan. Hal ini mengingat belum ada payung hukum yang melandasi agar kerugian-kerugian investor selaku korban dapat dikompensasi secara langsung.

Pada dasarnya, semua bentuk pelanggaran menimbulkan kerugian. Baik kerugian secara materiil (dinilai dengan uang) dan kerugian immateriil. Bahkan apabila pelanggaran materiil dapat diketahui secara jelas nilainya, maka kerugian immateriil justru dapat menjadi kerugian tak terbatas nilainya dan semakin berat. Akan tetapi, berkaitan dengan pembayaran ganti rugi disgorgement, hal tersebut berarti yang dihitung hanyalah pelanggaran dengan dampak kerugian materiil semata ${ }^{47}$ Perkembangan pasar modal melahirkan kejahatan kerah putih (white collar crime) yang dilakukan secara canggih mengakibatkan masyarakat investor dirugikan sebenarnya tidak menyadari akan kerugian yang dideritanya tersebut. ${ }^{48}$

Meski dalam UU Pasar Modal Pasal 111 menyebutkan bahwa setiap Pihak yang menderita kerugian sebagai akibat dari pelanggaran atas Undang-Undang ini dan atau peraturan pelaksanaannya dapat menuntut ganti rugi, baik sendiri-sendiri maupun bersama-sama dengan Pihak lain yang memiliki tuntutan yang serupa, terhadap Pihak atau Pihak-Pihak yang bertanggung jawab atas pelanggaran tersebut. Akan tetapi, dibutuhkan waktu, tenaga, biaya, pikiran, dan proses panjang untuk melalui proses peradilan tersebut. Hal ini mengingat, sebelum putusan pengadilan berkekuatan hukum tetap (inkracht) masih dapat dilakukan upaya hukum.

Hal ini tentu saja menyia-nyiakan kepercayaan masyarakat untuk berinvestasi di pasar modal. Padahal, pelanggaran di bidang pasar modal merupakan pelanggaran yang sifatnya teknis administratif. Ada tiga pola pelanggaran yang lazim terjadi yaitu: ${ }^{49}$

46 Lihat pada Investor Bulletin: How Victims of Securities Law Violation May Recover Money, www.sec.gov. org diakses pada 13 Januari 2020.

47 Nikmah Mentari, Op.Cit, hlm.64.

48 Inda Rahadiyan, Tinjauan Umum tentang Pasar Modal di Indonesia:Pengawasan Pasar Modal Pasca Terbentuknya Otoritas Jasa Keuangan, (Yogyakarta: UII Press, 2014), hlm.79

49 Freddy Saragih, "Pelanggaran di Bidang Pasar Modal”, dalam M. Irsan Nasarudin, Op.Cit. hlm.273. 
a. Pelanggaran yang dilakukan secar individual.

b. Pelanggaran yang dilakukan secara berkelompok.

c. Pelanggaran yang dilakukan langsung atau berdasarkan perintah atau pengaruh pihak lain.

Pelanggaran di pasar modal dapat dilihat dari berbagai sisi yaitu: ${ }^{50}$

a. Sisi pelakunya.

b. Cara kerja atau pola pelanggarannya

c. Akibat yang ditimbulkan

d. Pengenaan Sanksi

Kategori Pelanggaran pada UU Pasar Modal yakni tindak pidana berupa pelanggaran dan tindak pidana berupa kejahatan. ${ }^{51}$ Beberapa jenis tindak pidana Kejahatan di bidang pasar modal yakni:

1. Penipuan (Pasal 90 UU Pasar Modal). Spesifikasi mengenai penipuan, yaitu terbatas dalam kegiatan perdagangan efek yang meliputi kegiatan penawaran, pembelian, dan atau penjualan efek yang meliputi kegiatan penawaran, pembelian, dan atau penjualan efek yang terjadi dalam rangka penawaran umum, atau terjadi di bursa efek maupun di luar bursa efek atas efek emiten atau perusahaan publik. $^{52}$

2. Manipulasi Pasar (Pasal 91, 92, 93 UU Pasar Modal) atau kadang disebut sebagai gambaran semu, yaitu transaksi efek yang tidak mengakibatkan perubahan kepemilikan atau penawaran jual atau beli efek pada harga tertentu di mana pihak tersebut juga telah bersekongkol dengan pihak lain yang melakukan penawaran beli atau jual efek yang sama pada harga yang kurang lebih sama. ${ }^{53}$ Motif dari manipulasi pasar antara lain yakni meningkatkan, menurunkan atau mempertahankan harga efek. ${ }^{54}$

3. Perdagangan Orang Dalam/ Insider Trading (Pasal 95, 96, 97, 98 UU Pasar Modal). Secara teknis pelaku perdagangan orang dalam dapat dibedakan menjadi dua jenis, yaitu pihak yang mengemban kepercayaan secara langsung maupun tidak langsung dari emiten atau perusahaan publik atau disebut juga sebagai pihak yang berada dalam fiduciary position, dan pihak yang menerima informasi orang dalam dari pihak pertama (fiduciary position) atau dikenal dengan Tippees. ${ }^{55}$ Kemungkinan terjadinya perdagangan menggunakan informasi orang dalam yang melakukan transaksi atas efek

50 Neni Sri Imaniati dan Diana Wiyanti, "Perlindungan Hukum Terhadap Investor dan Upaya BAPEPAM Dalam Mengatasi Pelanggaran dan Kejahatan Pasar", Mimbar Hukum No.4, Tahun XVI, (Oktober-Desember 2000): 341.

51 Pasal 110 UUPM.

52 M. Irsan Nasarudin, Op.Cit, hlm. 262.

53 Ibid, h. 264-265

54 Ibid.

55 Ibid, h. 268. 
perusahaan di mana yang bersangkutan menjadi orang dalam. ${ }^{56}$ Selain itu, dapat pula dideteksi dari adanya peningkatan harga dan volume perdagangan efek sebelum diumumkannya informasi material kepada publik dan terjadinya peningkatan atau penurunan harga dan volume perdagangan yang tidak wajar. ${ }^{57}$ Sedangkan untuk tindak pidana pelanggaran terdapat pada Pasal 103 ayat (2), Setiap Pihak yang melakukan kegiatan tanpa memperoleh izin sebagaimana dimaksud dalam Pasal $32^{58}$ diancam dengan pidana kurungan paling lama 1 (satu) tahun dan denda paling banyak Rp1.000.000.000,00 (satu miliar rupiah). Kemudian, Pasal 105 Manajer Investasi dan atau Pihak terafiliasinya yang melanggar ketentuan sebagaimana dimaksud dalam Pasal $42^{59}$ diancam dengan pidana kurungan paling lama 1 (satu) tahun dan denda paling banyak Rp1.000.000.000,00 (satu miliar rupiah).

Terakhir, Pasal 109 Setiap Pihak yang tidak mematuhi atau menghambat pelaksanaan ketentuan sebagaimana dimaksud dalam Pasal $100^{60}$ diancam dengan pidana kurungan paling lama 1 (satu) tahun dan denda paling banyak Rp1.000.000.000,00 (satu miliar rupiah).
Selain pidana pelanggaran dan pidana kejahatan, pelanggaran admnistratif juga dapat menimbulkan kerugian secara materiil bagi investor. Pelanggaran dari aspek administrasi dimulai dari Pasal 25 sampai dengan Pasal 89 UU Pasar Modal berkaitan dengan kewajiban penyampaian laporan atau dokumen tertentu kepada OJK dan atau masyarakat. ${ }^{61} \mathrm{Hal}$ ini tidak berbeda dengan jenis pelanggaran yang sering dijumpai di pasar modal Amerika Serikat, sehingga membuat SEC melakukan investigasi yaitu misrepresentation atau pengabaian informasi penting terkait efek. ${ }^{62}$

\section{Pelanggaran administratif berfokus} pada pihak yang memperoleh izin OJK, memperoleh persetujuan OJK dan pihak yang memperoleh pendaftaran kepada OJK. Pelanggaran administratif atas kelalaian administrasi atau tidak dipenuhinya disclosure principle tersebut mengakibatkan investor 'salah langkah' dalam melakukan transaksi di bursa. Hal ini menunjukkan bahwa pelanggaran disclosure principle merupakan suatu penyesatan (mislead information) yang berisiko pada kerugian investor secara immateriil, namun dapat mengakibatkan kerugian materiil (domino effect). ${ }^{63}$

\footnotetext{
56 Ibid.

57 Ibid.

58 Pasal 32 Ayat (1) UUPM Yang dapat melakukan kegiatan sebagai Wakil Penjamin Emisi Efek, Wakil Perantara Pedagang Efek, atau Wakil Manajer Investasi hanya orang perseorangan yang telah memperoleh izin dari Bapepam.

59 Pasal 42 UUPM Perusahaan Efek yang bertindak sebagai Manajer Investasi atau Pihak terafiliasinya dilarang menerima imbalan dalam bentuk apa pun, baik langsung maupun tidak langsung, yang dapat mempengaruhi Manajer Investasi yang bersangkutan untuk membeli atau menjual Efek untuk Reksa Dana.

60 BAB XII terkait dengan Pemeriksaan. Lihat Pasal 100 UUPM.

61 Nikmah Mentari, Op.Cit, hlm.93.

62 How investigation work, How Investigations Work, https://www.sec.gov/enforce/how-investigations-work. html, diakses pada 10 Januari 2020.

63 Nikmah Mentari, Op.Cit, hlm.93.
} 
Perseroan memiliki kewajiban mengungkapkan informasi penting dalam laporan berkala dan laporan peristiwa penting perseroan kepada pemegang saham dan instansi pemerintah yang terkait sesuai dengan peraturan perundang- undangan yang berlaku secara tepat waktu, akurat, jelas dan objektif. ${ }^{64}$ Selain itu, laporan-laporan yang dapat mempengaruhi harga efek memiliki peranan penting bagi investor dalam mengambil keputusan berinvestasi atas suatu efek, selain efektivitas pengawasan oleh OJK. ${ }^{65}$

Berdasarkan pelanggaran-pelanggaran baik secara administratif maupun kejahatan di pasar modal tersebut, maka setiap pelanggaran yang secara nyata menimbulkan kerugian materiil dapat dikenakan disgorgement. Hal ini mengingat tujuan dari adanya pengenaan disgorgement yaitu mengembalikan keuntungan tidak sah kepada pemilik yang sah. ${ }^{66}$ Meskipun, sejauh ini RPOJK tidak mengatur spesifik terkait jenis pelanggaran yang harus memenuhi perintah pembayaran ganti rugi disgorgement, akan tetapi, segala jenis pelanggaran yang menimbulkan kerugian investor harus dikompensasi.

\section{B. Pertanggungjawaban Individu Atas Ganti Rugi Disgorgement yang Melibatkan Emiten}

Tanggung jawab dalam bahasa Inggris adalah responsibility atau dalam bahasa Belanda ialah aansprekelijk, yang artinya adalah bertanggung jawab, terikat, bertanggung jawab menurut hukum atas kesalahan atau akibat suatu perbuatan. ${ }^{67}$ Ada pula istilah lainnya yang berkaitan adalah pertanggungjawaban yang dalam bahasa Inggris adalah accountability dan dalam bahasa Belanda adalah aansprakelijkheid yang artinya juga tanggung jawab, keterikatan, tanggung jawab dalam hukum memikul tanggung jawab. ${ }^{68}$

Pada Pasal 1365 KUHPerdata "Setiap orang bertanggung jawab tidak saja untuk kerugian yang disebabkan perbuatannya, tetapi juga untuk kerugian yang disebabkan kelalaian atau kurang hati-hatinya." Pasal ini digunakan dalam gugatan Perbuatan Melawan Hukum (PMH).

Dalam KUHPerdata dikenal ada 2 (dua) jenis tanggung jawab, yaitu: ${ }^{69}$

64 M. Irsan Nasarudin, Op.Cit, hlm.236

65 Jusuf Anwar, Pasar Modal Sebagai Sarana Pembiayaan dan Investasi, Seri Pasar Modal I, (Bandung: Alumni, 2005), hlm.105.

66 Nikmah Mentari, Op.Cit, hlm.94.

67 Fockema Andrea, diterjemahkan oleh Adiwinata A. Teloeki dan H. Boerchanudin St. Batoeh, dalam Trusto Subekti, "Batasan Tanggung Jawab Direksi atas Kerugian Perusahaan", Jurnal Dinamika Hukum Vol.8, No.1, (2008): 21

68 Ibid.

69 Trusto Subekti,Ibid. hlm.22. 
1. Tanggung jawab berdasarkan kesalahan, artinya seseorang dapat dimintai pertanggungjawaban atas kesalahan yang telah diperbuatnya dan akibat kesalahannya itu telah menimbulkan kerugian bagi orang lain;

2. Tanggung jawab berdasarkan risiko, artinya seseorang dapat dimintai pertanggungjawaban atas kerugian yang diderita oleh orang lain bukan karena kesalahan yang bersangkutan, melainkan sebagai risiko yang ditanggungnya karena kesalahan orang lain dan orang tersebut adalah menjadi bawahannya atau menjadi tanggungnya, atau dalam pengawasannya. Tanggung jawab karena kesalahan sebagaimana telah diatur dalam Pasal 1365 KUHPerdata dan Pasal

1367 KUHPerdata merupakan bentuk klasik pertanggungjawaban perdata. ${ }^{70}$

Menurut Moeljatno dikatakan adanya kemampuan bertanggung jawab harus memiliki 2 (dua) hal yaitu: ${ }^{71}$

1. Kemampuan untuk membeda-bedakan antara perbuatan yang baik dan yang buruk, yang sesuai hukum dan melawan hukum;

2. Kemampuan untuk menentukan kehendaknya menurut keinsyafan tentang baik dan buruknya perbuatan tadi.

Indikator mengenai kemampuan bertanggung jawab dapat dikembangkan lebih lanjut dari pernyataan Moeljatno, yaitu yang pertama merupakan faktor akal (intelectual factor) yang dapat membeda-bedakan antara perbuatan yang diperbolehkan dan yang tidak. ${ }^{72}$ Kedua, adalah faktor perasaan atau kehendak (volitional factor) yang dapat menyesuaikan tingkah lakunya dengan keinsyafan atas nama yang diperbolehkan dan mana yang tidak. ${ }^{73}$ Pendapat Moeljatno tersebut berada dalam konteks kemampuan bertanggung jawab pada aspek hukum perdata. Indikator kemampuan bertanggung jawab juga dapat dipergunakan dalam menilai suatu tindakan atau perbuatan seorang direksi dapat tidaknya dipertanggung jawabankan (accountability) kepadanya. ${ }^{74}$

Pertanggungjawaban dari aspek pidana merujuk pada Pasal 2 jo Pasal 55 Kitab UndangUndang Hukum Pidana (KUHP). ${ }^{75}$ Dalam hal ini pidana penjara dan pidana denda ditekankan

70 Ibid.

71 Ibid.

72 Ibid, hlm. 24

73 Ibid.

74 Ibid.

75 Pasal 2 KUHP menyebutkan ketentuan pidana dalam perundang-undangan Indonesia diterapkan bagi setiap orang yang melakukan sesuatu tindak pidana di Indonesia. Hal ini menegaskan tentang tanggung jawab pelaku pidana yang berlaku di Indonesia. Sedangkan pada Pasal 55 KUHP, yang dimaksud orang yang dapat dimintai pertanggungjawaban yakni pada ayat (1) Dipidana sebagai pelaku tindak pidana : 1 . Mereka yang melakukan, yang menyuruh lakukan, dan yang turut serta melakukan perbuatan; 2 mereka yang dengan memberi atau menjanjikan sesuatu dengan menyalahgunakan kekuasaan atau martabat, dengan kekerasan, ancaman atau penyesatan, atau dengan memberi kesempatan, sarana atau keterangan, sengaja menganjurkan orang lain supaya melakukan perbuatan. Pada ayat (2) Terhadap penganjur, hanya perbuatan yang sengaja dianjurkan sajalah yang diperhitungkan, beserta akibat-akibatnya. Hal ini menunjukkan bahwa secara pidana, yang dapat dimintai pertanggungjawaban atas suatu kejahatan hanyalah orang sebagai individu (naturlijk persoon). 
bagi orang (naturlijk person) sebagai individu. Sedangkan pada UU Pasar Modal, tanggung jawab dibebankan kepada yang dimaksud sebagai 'Pihak'. Pihak berdasarkan Pasal 1 Angka 23 UU Pasar Modal adalah orang perseorangan, perusahaan, usaha bersama, asosiasi, atau kelompok yang terorganisasi. Lebih lanjut, emiten dalam hal ini bertindak sebagai Perseroan Terbatas Terbuka (PT Tbk). Emiten merupakan Pihak yang melakukan penawaran umum dalam rangka menjaring dana bagi kegiatan usaha perusahaan atau pengembangan usaha perusahaan. ${ }^{76}$

Selain itu, terdapat 4 (empat) keharusan yang dapat dilakukan emiten beraktivitas di pasar modal, yaitu: ${ }^{77}$

1. Keterbukaan informasi publik (Pasal 1 Angka 25 UU Pasar Modal). Pelaksanaan keterbukaan dilakukan dalam 3 (tiga) tahapan yaitu :

a. Tahap keterbukaan saat emiten melakukan penawaran umum di pasar primer.

b. Tahap keterbukaan saat emiten mencatat dan memperdagangkan saham di bursa efek pada pasar sekunder.

c. Tahap keterbukaan apabila terjadi peristiwa penting yang laporannya harus disampaikan secara tepat waktu kepada OJK dan bursa efek.
2. Emiten wajib menyampaikan laporan berkala yang terdiri dari:

a. laporan tahunan dan laporan keuangan tengah tahunan,

b. Peningkatan likuiditas.

c. Pemantauan harga efek.

d. Menjaga hubungan baik dengan investor.

Di pasar modal, Pihak yang berpotensi melakukan pelanggaran adalah emiten atau perusahaan publik dan pihak-pihak yang mempunyai posisi strategis di dalam perusahaan seperti direksi, komisaris, dan pemegang saham utama. $^{78}$ Pihak lain yang berpotensi melakukan pelanggaran ialah para profesional di bidang pasar modal, misalnya penasehat investasi, manajer investasi, akuntan, konsultan hukum, penilai dan notaris. $^{79}$

Terkait adanya pelanggaran di pasar modal, siapapun dapat dimintai pertanggung jawaban pidana, perdata maupun administratif. Pertanggung jawaban pidana ditegakkan ketika terjadi tindak pidana berupa pelanggaran dan kejahatan. Pasal 110 UU Pasar Modal membedakan perbuatanperbuatan yang termasuk pelanggaran atau kejahatan. Sanksi pidana tersebut meliputi ancaman pidana penjara dan denda atau pidana kurungan dan denda.

\footnotetext{
76 M. Irsan Nasarudin, dkk, Op.Cit, hlm. 151. Lihat pula Pasal 1 Angka 6 UU Pasar Modal.

77 Ibid. Lihat pula Gunawan Widjaja, Seri Pengetahuan Pasar Modal, Cet. I, (Jakarta: Prenada Media, 2006), hlm. 56-57

78 Neni Sri Imaniati dan Diana Wiyanti, Op.Cit, h.357.

79 Ibid.
} 
Apabila korporasi melakukan suatu tindak pidana, maka hanya dapat dibebankan pidana denda. J. E Sahetapy berpendirian bahwa korporasi bukan seorang pribadi, meskipun dalam kenyataannya ia mengadakan aktivitas sebagai seorang pribadi, membuat transaksi dalam bidang perdagangan dan keuangan, membayar pajak dan sebagainya. Korporasi adalah suatu 'persona ficta' atau 'legal fiction' atau suatu 'fiksi hukum'. Dengan demikian korporasi tidak bisa berbicara, tidak mengeluarkan suara, dan tidak memiliki pikiran. ${ }^{80}$ Oleh karena itu, pidana kurungan dan penjara tidak mungkin diberlakukan pada korporasi.

Akan tetapi, apabila terjadi pelanggaran yang melibatkan korporasi, daripada sanksi pidana yang hanya berupa pidana denda, sanksi administratif biasanya turut mengikuti dan lebih berat. Sanksi administratif pada pasar modal diatur pada Pasal 102 ayat (2) UU Pasar Modal yang berupa:
a. peringatan tertulis;
b. denda yaitu kewajiban untuk membayar sejumlah uang tertentu;
c. pembatasan kegiatan usaha;
d. pembekuan kegiatan usaha;
e. pencabutan izin usaha;

f. pembatalan persetujuan; dan

g. pembatalan pendaftaran.

Sanksi pada huruf c sampai dengan huruf g akan memberikan dampak kerugian yang lebih besar baik bagi korporasi, investor, para stakeholder dan pihak ketiga. Padahal, dari segi keperdataan kedudukan Perseroan Terbatas sebagai badan hukum tidak bisa dilepaskan dari teori fiksi (fictie theorie) yang dikenal dalam ilmu hukum.

Teori ini dikemukakan pertama kali oleh Von Savigny. Menurut teori ini, badan hukum itu dianggap sebagai hal yang abstrak, tidak nyata, karena tidak mempunyai kekuasaan untuk menyatakan kehendak. Badan Hukum dianggap seolah-olah manusia (artificial person). Oleh karena itu, tindakan badan hukum dianggap juga sebagai tindakan manusia. Jika manusia dalam tindakannya mempunyai tanggung jawab, badan hukum juga bertanggung jawab atas tindakan yang dilakukannya. ${ }^{81}$ Perseroan sebagai badan hukum, adalah makhluk hukum (a creature of the law) yang memiliki hal-hal berikut: ${ }^{82}$

1. Kekuasaan (power) dan kapasitas yang dimilikinya karena diberikan hukum kepadanya, dan berwenang berbuat dan bertindak sesuai dengan kewenangan yang diberikan, dalam Anggaran Dasar (AD).

80 J. E sahetapy, Kejahatan Korporasi, dalam Ramelan, "Pertanggung Jawaban Korporasi dalam Hukum Pidana", Jurnal Hukum Prioris Vol. 1, No. 2, (Februari 2007): 118.

81 Shinta Ikayani Kusumawardani, "Pengaturan Kewenangan, dan Tanggung Jawab Direksi Dalam Perseroan Terbatas (Studi Perbandingan Indonesia dan Australia)", Jurnal Magister Ilmu Hukum Udayana, Vol.2, No.1, (2013): 7. Lihat pula Kurniawan, "Tanggung Jawab Direksi Dalam Kepailitan Perseroan Terbatas Berdasarkan Undang-Undang Perseroan Terbatas", Mimbar Hukum Vol.24, No.2, (Juni 2012) (Selanjutnya disebut Kurniawan I): 216

82 Philip J. Scaletta dalam Zarman Hadi, Karakteristik Tanggung Jawab Pribadi Pemegang Saham, dalam Kurniawan, "Tanggung Jawab Pemegang Saham Perseroan Terbatas Menurut Hukum Positif", Mimbar Hukum Vol.26, No. 1, (Februari 2014) (Selanjutnya disebut Kurniawan II): 76. 
2. Mempunyai kekuasaan diatur secara tegas (express power) seperti untuk memiliki kekayaan, menggugat, dan digugat atas nama perseroan.

3. Tetapi ada juga kekuasaan yang bersifat (implicit power) yakni berwenang melakukan apa saja, asal dilakukan secara reasonable dan penting (reasonably necessary) untuk perseroan, seperti menguasai atau men-transfer barang, meminjamkan uang, memberi sumbangan, dan sebagainya.

Pertanggung jawaban secara perdata di pasar modal diatur pada Pasal 111 UU Pasar Modal menyebutkan "Setiap Pihak yang menderita kerugian sebagai akibat dari pelanggaran atas Undang-Undang ini dan atau peraturan pelaksanaannya dapat menuntut ganti rugi, baik sendiri-sendiri maupun bersama-sama dengan Pihak lain yang memiliki tuntutan yang serupa, terhadap Pihak atau Pihak-Pihak yang bertanggung jawab atas pelanggaran tersebut”. Hal ini menunjukkan pertanggung jawaban keperdataan dapat bersifat tanggung renteng. Pada umumnya, pertanggung jawaban perdata juga menarik korporasi sebagai pihak tergugat.

Korporasi, dalam hal ini Perseroan Terbatas Terbuka (PT Tbk) atau emiten, juga merupakan artificial person. Sebagai "artificial person", perseroan tidak mungkin dapat bertindak sendiri. Perseroan tidak memiliki kehendak untuk menjalankan dirinya sendiri. Oleh karena itu diperlukan orang-orang yang memiliki kehendak yang akan menjalankan perseroan tersebut sesuai maksud dan tujuan pendirian perseroan. ${ }^{83}$ Dalam hal ini, setiap tindakan emiten atau corporate action dilakukan oleh direksi yang bertugas mengurus sehari-hari kepentingan perseroan (daily management).

Terkait dengan pengelolaan emiten selaku PT Tbk, pada prinsipnya tunduk pada UUPT. Secara organisatoris, UUPT menyatakan bahwa suatu Perseroan sekurang-kurangnya harus diurus oleh satu orang atau lebih anggota Direksi, ${ }^{84}$ dengan pengecualian bagi Perseroan yang bidang usahanya melakukan pengerahan dana masyarakat, Perseroan yang menerbitkan surat pengakuan utang, atau Perseroan terbatas terbuka, harus memiliki sekurang-kurangnya dua orang anggota Direksi. $^{85}$

Orang yang tergabung dalam keanggotaan Direksi dikenal dengan sebutan Direktur. Dalam hal perseroan memiliki lebih dari satu orang Direktur dalam Direksi, maka salah satu anggota Direksi tersebut diangkat sebagai Direktur Utama (Presiden Direktur). ${ }^{86}$ Hal inilah yang menjadi karakteristik kepengurusan Perseroan Terbuka, yakni jumlah anggota direksinya berjumlah lebih dari satu dan terdapat posisi direktur

83 Dandy Firmansyah, Op.Cit, hlm.40

84 Pasal 92 ayat 3 UUPT

85 Pasal 92 ayat 4 UUPT

86 Gunawan Widjaja, Seri Pengetahuan Pasar Modal, dalam Dandy Firmansyah, "Tanggung Jawab Direksi atas Pengendalian Internal Dalam perseroan Terbuka", Skripsi Sarjana Ilmu Hukum, (Jakarta: Universitas Indonesia, 2012), Tidak Dipublikasikan, hlm. 41. 
utama/presiden direktur dalam komposisi direksinya. ${ }^{87}$

Dalam melakukan pengurusan perseroan sehari-hari sebagai bagian dari tanggung jawab dan tugas direksi, dikenal adanya prinsip fiduciary duties. Prinsip fiduciary duties ini, seorang direktur memiliki hubungan fidusia dengan perseroan dimana direktur tersebut telah mengikatkan diri dengan atau kepada perseroan untuk bertindak dengan iktikad baik (bonafide) untuk kemanfaatan atau keuntungan perseroan. Direktur harus dijalankan untuk memajukan kepentingan perseroan. ${ }^{88}$ Sehingga, terdapat relasi integral antara kepentingan perseroan dan iktikad baik yang kedua-duanya harus dijalankan oleh direksi. ${ }^{89}$

Direksi yang memperoleh hak dan dibebani kewajiban untuk memutuskan apa yang penting untuk perseroan, dan bagaimana melaksanakannya berdasarkan pertimbangan praktis, putusannya bila dilakukan dengan itikad baik dan tujuan yang benar, tidak terbuka bagi pengadilan untuk ditinjau kembali. ${ }^{90}$ Dalam melaksanakan tugas dan wewenangnya, Direksi harus bertolak dari landasan bahwa tugas dan kedudukan yang diperolehnya berdasarkan dua prinsip dasar, yaitu pertama kepercayaan yang diberikan perseroan kepadanya (fiduciary duty), dan kedua prinsip yang merujuk pada kemampuan serta kehati-hatian tindakan direksi (duty of skill and care). ${ }^{91}$

Pengertian fiduciary duty sendiri yakni central to the role of a director is the fiduciary role-being trustworthy in acting in the best interests of those whom the director represents..$^{92}$ Prinsip ini termanifestasi dalam Pasal $92^{93}$ UUPT. Relasi antara fiduciary duty dan pertanggung jawaban (accountability) atas suatu tindakan seorang direksi dapat dilihat dari apakah suatu tindakan atau perbuatan yang dilakukannya (responsibility) berdasar atas wewenang (authority), termasuk di dalamnya harus pula berdasar pada prinsip fiduciary duty, dan tindakan atau perbuatan (responbility) tersebut didukung oleh keadaan yang seimbang antara tugas kewajiban (duty atau responbility) dengan kemampuan melaksanakan tugas kewajiban (capability).

87 Ibid.

88 Pearli Koh dan Victor Teo dalam dari Cornelius Simanjuntak dan Natalie Mulia, Organ Perseroan Terbatas, Cetakan pertama, (Jakarta: Sinar Grafika, 2009), hlm. 39.

89 Cornelius Simanjuntak dan Natalie Mulia, Ibid.

90 Barwick CJ, Me Tiernan and Kitto JJ in Harlowe's Nominees Pry Ltd v Woodside (Lakes Ellfrance) Oil Co NL (1968) 121 CLR 483 at 493 dalam Chatamarrasjid Ais, 2001, "Fiduciary Duty" Sebagai Standar Para Direksi Dalam Melaksanakan Tugasnya", Jurnal Hukum dan Pembangunan No. 1, Tahun XXXI, (JanuariMaret 2001): 63.

91 Ibid, h.64

92 John L. Colley, et.all, The McGraw-Hill Executive MBA Series: Corporate Governance, (New York: The McGraw-Hill Companies, Inc, 2003), p. 16.

93 Pasal 92 UUPT (1) Direksi menjalankan pengurusan Perseroan untuk kepentingan Perseroan dan sesuai dengan maksud dan tujuan Perseroan. Ayat (2) Direksi berwenang menjalankan pengurusan sebagaimana dimaksud pada ayat (1) sesuai dengan kebijakan yang dipandang tepat, dalam batas yang ditentukan dalam undang-undang ini dan/ atau anggaran dasar. 
Suatu tindakan hukum yang dilakukan seorang direksi untuk dapat dipertanggung jawabkan (capability). ${ }^{94}$

Prinsip ini juga ditegaskan oleh Sutan Remy Sjahdeini yang mengatakan bahwa kedua unsur 'kepentingan dan tujuan/usaha perseroan' dan 'iktikad baik dan penuh tanggung jawab' sebagai bagian integral dari pengurusan perseroan oleh direksi harus dipenuhi secara kumulatif dan bukan alternatif. $^{95}$ Direksi PT karenanya harus memiliki kemampuan untuk menilai dan kemudian mengambil keputusan apakah perbuatan hukum yang akan dilakukan telah sejalan dengan 'maksud dan tujuan serta kegiatan usaha perseroan' dan tentunya direksi PT tersebut harus senantiasa mengacu kepada anggaran dasar PT yang dipimpinnya atau diurusnya. ${ }^{96}$

Direksi memiliki 2 (dua) fungsi yaitu fungsi pengaturan (manajemen) dan fungsi perwakilan (representasi). ${ }^{97}$ Fungsi manajemen dalam hukum Jerman disebut Geschaftsfuhrungsbefugnis. Sedangkan prinsip mewakili perusahaan di luar pengadilan menyebabkan Perseroan sebagai badan hukum akan terikat dengan transaksi atau kontrak-kontrak yang dibuat oleh direksi atas nama dan untuk kepentingan Perseroan, fungsi representasi ini dalam hukum jerman disebut Vertretungsmacht..$^{98}$

Direksi sebagai penerima kuasa dari perseroan untuk menjalankan perseroan sesuai dengan kepentingannya untuk mencapai tujuan perseroan sebagaimana telah digariskan dalam anggaran dasar perseroan. ${ }^{99}$ Pada sisi lain direksi diperlakukan sebagai karyawan perseroan, dalam hubungan atasan dan bawahan dalam perjanjian perburuhan yang mana berarti direksi tidak diperkenankan untuk melakukan sesuatu yang bukan tugasnya. ${ }^{100}$ Oleh karena itu, sifat pertanggung jawaban renteng dan pertanggung jawaban pribadi direksi menjadi sangat relevan, dalam hal direksi melakukan penyimpangan atas kuasa dan perintah perseroan untuk kepentingan perseroan. ${ }^{101}$

Apabila direksi melakukan tindakan yang jatuh di luar kekuasaan yang disebut dengan tegas (express power) maupun kekuasaan implisit (implicit power), dapat dikategorikan ultra vires yang berarti berada di luar kegiatan dan di luar wewenang (unauthorized activities). ${ }^{102}$

\footnotetext{
94 Trusto Subekti, Op.Cit, hlm. 23.

95 Sutan Remy Sjahdeini dalam Cornelius Simanjuntak dan Natalie Mulia, Op.Cit, hlm.39

96 Cornelius Simanjuntak dan Natalie Mulia, Ibid, hlm. 50.

97 Ridwan Khairandy, Perseroan Terbatas, dalam Siti Hapsah Isfandariyah, "Tanggung Jawab Direksi atas Pelanggaran Fiduciary Duty dan Menyebabkan Perseroan Pailit", Tesis Magister Ilmu Hukum, (Yogyakarta: Universitas Islam Indonesia, 2012), hlm.93.

98 Dandy Firmansyah, Op.Cit, hlm. 42

99 Jono, Hukum Kepailitan, dalam Siti Hapsah Isfandariyah, Op.Cit, hlm. 94-95.

100 Ibid.

101 Siti Hapsah Isfandariyah, Ibid, hlm. 95.

102 Kurniawan II, Op.Cit: 76.
} 
Terhadap tindakan direksi yang merugikan perseroan, dengan syarat yang dilakukannya itu berada di luar batas kewenangan yang diberikan kepadanya oleh anggaran dasar, maka akibat dari tindakan direksi itu dapat tidak diakui oleh perseroan atau dianggap bukan sebagai tindakan perseroan. ${ }^{103}$ Selain itu, hal ini dapat berlaku pula bagi Dewan Komisaris. ${ }^{104}$

Oleh karena itu, sebagai pihak pengendali jalannya perseroan untuk melakukan perbuatan hukum maupun perbuatan perusahaan, apabila Direktur dan/atau Komisaris melakukan tindakan melalui emiten dengan maksud dan menikmati keuntungan dari perbuatan ilegal di pasar modal yang kemudian menimbulkan kerugian bagi investor, maka direksi dan dewan komisaris baik secara sendirisendiri maupun bersama-sama bertanggung jawab untuk mengembalikan keuntungan disgorgement tersebut.

Tidak hanya direksi dan dewan komisaris saja yang dapat dimintai pertanggung jawaban untuk membayar disgorgement apabila bertindak ultra vires dan secara persona menikmati setiap keuntungan ilegal dari hasil pelanggaran. akan tetapi, pemegang saham mayoritas atau pemegang saham pengendali juga dapat dikenakan pembayaran disgorgement apabila melakukan pelanggaran dan menikmati hasil keuntungan atas pelanggaran tersebut.

Hal ini mengingat terdapat prinsip piercing the corporate veil yang menyingkap tanggung jawab terbatas pemegang saham utama/pengendali untuk bertanggung jawab secara pribadi baik sendiri-sendiri maupun bersama-sama atas tindakan yang dapat merugikan perseroan. Pertanggung jawaban ini juga termanifestasi pada Pasal 3 ayat (2) huruf $\mathrm{b}$ dan c UUPT. ${ }^{105}$ Doktrin piercing the corporate veil ini seperti yang dianut dalam UU PT 2007 tersebut hampir sama dengan asas misbruik van rechtspersonen seperti yang dianut di Belanda. ${ }^{106}$

Pasal 3 UU PT tersebut, menurut Gunawan Widjaya, mengemukakan hal yang menyebabkan terjadinya piercing the corporate veil yaitu : 107

103 Sjawie, Hasbullah F. “Tanggung Jawab Terbatas atas Tindakan Ultra Vires”, Jurnal Hukum Prioris, Vo. 6, No. 1, (2017), hlm. 30

104 Pasal 114 UUPT ayat (1) Dewan Komisaris bertanggung jawab atas pengawasan Perseroan sebagaimana dimaksud dalam Pasal 108 ayat (1). ayat (2) Setiap anggota Dewan Komisaris wajib dengan itikad baik, kehati-hatian, dan bertanggung jawab dalam menjalankan tugas pengawasan dan pemberian nasihat kepada Direksi sebagaimana dimaksud dalam Pasal 108 ayat (1) untuk kepentingan Perseroan dan sesuai dengan maksud dan tujuan Perseroan. Ayat (3) Setiap anggota Dewan Komisaris ikut bertanggung jawab secara pribadi atas kerugian Perseroan apabila yang bersangkutan bersalah atau lalai menjalankan tugasnya sebagaimana dimaksud pada ayat (2).

105 Pasal 3 UUPT ayat (1) Pemegang saham Perseroan tidak bertanggung jawab secara pribadi atas perikatan yang dibuat atas nama Perseroan dan tidak bertanggung jawab atas kerugian Perseroan melebihi saham yang dimiliki. Ayat (2) Ketentuan sebagaimana dimaksud pada ayat (1) tidak berlaku apabila:

.; b. pemegang saham yang bersangkutan baik langsung maupun tidak langsung dengan itikad buruk memanfaatkan Perseroan untuk kepentingan pribadi; c. pemegang saham yang bersangkutan terlibat dalam perbuatan melawan hukum yang dilakukan oleh Perseroan;......

106 Verina Yuwono Setianto, "Pertanggungjawaban Pribadi Direksi Pada Perseroan Terbatas yang Pailit", Mimbar Yustisia, Vol.1, No.2, (Desember 2017): 211.

107 Gunawan Widjaja, Risiko Hukum Sebagai Direksi, Komisaris dan Pemilik PT, dalam Kurniawan II, Op.Cit, hlm.80. 
1. Terkait dengan teori keagenan, di mana pemegang saham dengan itikad buruk telah memanfaatkan perseroan untuk kepentingan dirinya pribadi. Dalam konteks yang demikian, berarti perseroan semata-mata hanya melaksanakan apa yang menjadi tujuan dan objektif dari pemegang saham. Pemegang saham dalam hal ini berlindung di balik pertanggungjawaban terbatas perseroan, sedangkanperseroansendiridimanfaatkan untuk kepentingan pribadinya. Jadi jelaslah dalam konteks ini, pemegang saham yang tidak memiliki itikad baik dan dilindungi oleh hukum. Piercing the corporate veil belaku dalam hal ini bagi pemegang saham yang memanfaatkan perseroan untuk kepentingannya pribadi.

2. Hal ketiga ini menunjukkan pada tindakan pemegang saham yang secara bertentangan dengan hukum (fraud). Dalam hal ini perlu diperhatikan adagium bahwa siapa yang telah menerbitkan kerugian pada seseorang lain,bertanggung jawab atas kerugian yang diterbitkannya tersebut. Sebagai suatu artificial person, perseroan terbatas tidaklah memiliki kehendak. Dalam keadaan di mana kehendak perseroan adalah kehendak pemegang saham,maka jelas yang bertanggung jawab adalah pemegang saham tersebut.

Pada yurisprudensi Common Law menyimpulkan adanya tiga doktrin umum bagi kemungkinan dapat dilanggarnya prinsip tanggung jawab terbatas atau dimungkinkannya Piercing The Corporate Veil, yakni: ${ }^{108}$

1. Doktrin “Instrumentality", yang pendekatannya mengacu pada 3 (tiga) faktor sebagai berikut: a. Adanya kontrol/pengendalian atas PT, sehingga PT tidak mempunyai eksistensi yang mandiri.

b. Pengendalian tersebut berpengaruh atas dilakukannya tindakan melalaikan kewajiban.

c. Atas tindakan lalai tersebut menimbulkan kerugian.

2. Doktrin "Alter Ego", yang berpendapat bahwa Piercing The Corporate Veil dapat diterapkan dalam hal:

a. Kepentingan Pemilik Saham mengalahkan kepentingan PT; dan

b. Sulit untuk membedakan atau mengenali entitas pribadi Pemegang Saham dari entitas PT yang bersangkutan.

3. Doktrin "identity", yang menyerahkan permasalahan kesatuan atau pemisahan kekayaan perseroan dalam pembuktian di pengadilan secara per kasus.

Prinsip piercing the corporate veil pada pemegang saham pengendali dan doktrin ultra vires terhadap direksi dan dewan komisaris dapat diterapkan untuk membayar ganti rugi disgorgement apabila bertindak selain sebagai pelaku pelanggaran, sekaligus penerima dan penikmat keuntungan ilegal dari sebuah pelanggaran di pasar modal.

Selain itu, terkait dengan emiten sebagai perusahaan go public, ketentuan berkenaan dengan status badan hukum sebuah PT tetap tunduk pada UUPT. Akan tetapi, kemungkinan pihak lain yang terlibat dengan pihak-pihak yang dapat melakukan suatu pelanggaran dengan melibatkan emiten adalah pihak yang 
terafiliasinya. Pasal 1 Angka 1 UUPM yang dimaksud dengan Afiliasi adalah:

a. hubungan keluarga karena perkawinan dan keturunan sampai derajat kedua, baik secara horizontal maupun vertikal;

b. hubungan antara Pihak dengan pegawai, direktur, atau komisaris dari Pihak tersebut;

c. hubungan antara 2 (dua) perusahaan di mana terdapat satu atau lebih anggota direksi atau dewan komisaris yang sama;

d. hubungan antara perusahaan dengan Pihak, baik langsung maupun tidak langsung, mengendalikan atau dikendalikan oleh perusahaan tersebut;

e. hubungan antara 2 (dua) perusahaan yang dikendalikan, baik langsung maupun tidak langsung, oleh Pihak yang sama; atau

f. hubungan antara perusahaan dan pemegang saham utama.

Hal ini menunjukkan adanya peluang untuk melakukan pelanggaran di pasar modal bahwa dapat dilakukan oleh orang sebagai subjek individu. Meski kemudian melibatkan emiten dalam melakukan pelanggaran, akan tetapi, pada dasarnya disgorgement ialah pengembalian keuntungan. Pengembalian keuntungan itu menjadi beban bagi pelaku pelanggaran, pelaku yang memiliki kehendak, niat, akal dan pikiran serta yang menikmati keuntungan tersebut.
Dalam hal ini, yang berhubungan dengan emiten itu sendiri biasanya berkaitan dengan 'orang dalam'. Dari sisi pertanggung jawaban berdasarkan kesalahan, emiten selaku entitas yang memang dapat diperlakukan layaknya orang, memang selalu turut bertanggung jawab atas pelanggaran yang dilakukan. Akan tetapi, pihak yang menikmati atau menerima keuntungan ilegal dari adanya pelanggaran tersebut adalah pelaku secara in persona.

Oleh karena itu, menurut pengamat pasar modal sekaligus investor ternama, Irwan Ariston Napitupulu, menyatakan bahwa pembayaran ganti rugi tidak seharusnya menggunakan uang perusahaan, tetapi menggunakan harta pribadi pihak yang bertanggung jawab atas pelanggaran tersebut sesuai dengan undang-undang. ${ }^{109}$

Merujuk pada filosofi dan tujuan dari pembayaran ganti rugi disgorgement itu sendiri mengembalikan keuntungan ilegal pelaku saat terjadi pelanggaran. Disgorgement bersifat perintah pengembalian yang mana hal ini diluar dari sanksi atas pelanggaran itu sendiri. Perintah tersebut ditujukan kepada pihak yang menikmati keuntungan ilegal. Sehingga penerima keuntungan ilegal secara in persona wajib untuk mematuhi perintah tersebut. Sebaliknya, apabila emiten, juga menerima keuntungan ilegal tersebut atau dengan kata lain keuntungan hasil pelanggaran dimasukkan ke dalam kas perusahaan, maka emiten tidak

109 Tanggapan pengamat soal rencana OJK membentuk disgorgement fund, <https://investasi.kontan.co.id/ news/tanggapan-pengamat-soal-rencana-ojk-membentuk-disgorgement-fund $>$ diakses pada 18 April 2019 
perlu dibebankan untuk membayar ganti rugi disgorgement. Hal ini mengingat keuntungan emiten merupakan keuntungan investor. Merujuk pada status emiten sebagai artificial person yang tentu saja tidak memiliki kehendak melakukan pelanggaran. Adapun jika Emiten menerima keuntungan tersebut, juga bukan kehendaknya.

Selain itu, Pasal 3 ayat (1) RPOJK Penetapan Perintah Tertulis sehubungan dengan Disgorgement dilakukan bersamaan dengan ditetapkannya sanksi administratif kepada Pihak yang melakukan pelanggaran peraturan perundang-undangan di bidang Pasar Modal. Dengan demikian, apabila Emiten sebagai salah satu pihak yang melakukan pelanggaran sehingga menimbulkan kerugian bagi investor, maka akan mendapatkan kerugian berlipat ganda (double loss), yakni sanksi administratif dan ganti rugi disgorgement. Sanksi administratif itu sendiri telah memberikan efek kerugian besar bagi emiten.

Misalnya, penurunan harga efek secara drastis dan cacat profile pada profile company sebagai sanksi sosial dihadapan publik serta sanksi lainnya oleh bursa efek. Apabila kemudian akibat dari kelalaian atau iktikad buruk seseorang atau sekelompok orang sehingga pelanggaran di pasar modal berkaitan dengan emiten, maka sudah sewajarnya tanggung jawab disgorgement dikenakan pada orang atau sekelompok yang menikmati keuntungan ilegal tersebut. Bukan pada emiten sebagai legal entity.

Emiten memiliki peranan penting sebagai salah satu pemain di pasar modal. Oleh karena itu, penting sekali kedudukan emiten untuk dipertahankan sebagai entitas yang merdeka atas beban yang seharusnya tidak dilakukan. Karena eksistensi emiten tidak lain juga demi kepentingan investor dan pasar modal di suatu negara.

Mengingat disgorgement merupakan perintah dari otoritas yang berwenang, maka tanpa menunggu adanya penyidikan maupun putusan pengadilan yang menyatakan bersalah, perintah tersebut bersifat sertamerta dan mengikat pada pihak yang dianggap melakukan pelanggaran dengan menimbulkan kerugian investor. Oleh karena itu, pihak penerima perintah haruslah dipertegas dan diperjelas. Terlebih apabila berkaitan dengan emiten sebagai pelaku pelanggaran.

Selain itu, disgorgement bukan merupakan sebuah sanksi hukum, melainkan remedial action atau tindakan pemulihan. Sehingga, tidak dapat dikenakan pertanggung jawaban secara tanggung renteng. Akan tetapi, harus bersifat apple to apple yaitu individu penerima keuntungan ilegal mengembalikan sejumlah keuntungaan tersebut kepada pihak yang dirugikan. Hal ini merujuk pada keadilan korektif, dimana tujuan dari disgorgement adalah mengembalikan semua pihak pada posisi sebelum adanya pelanggaran sehingga menimbulkan kerugian. 


\section{Penutup}

Disgorgement sebagai bentuk lembaga hukum baru dalam sistem hukum Indonesia, khususnya pada hukum pasar modal Indonesia, merupakan suatu terobosan hukum progresif. Tujuannya ialah memberikan perlindungan dan keadilan bagi investor sebagai pihak yang seringkali dirugikan dan memiliki posisi lemah khususnya investor ritel atau perorangan. Pembayaran ganti kerugian investor melalui disgorgement harus melihat pada pihak penerima keuntungan yang secara sadar, berakal dan berkehendak melakukan pelanggaran serta menikmati hasil pelanggara tersebut.

Hal ini tak lain karena pihak yang memiliki kehendak, pikiran dan mampu bergerak untuk melakukan suatu pelanggaran serta menikmati keuntungannya ialah orang secara individu (natuurlijke person). Oleh karena itu, apabila pelanggaran melibatkan emiten dan menimbulkan kerugian bagi investor, pihak sesungguhnya yang melakukan pelanggaran dan menikmati keuntungan tersebutlah yang harus bertanggung jawab secara pribadi (persoonljke aansprakeljkheid, personal liability). Sehingga dalam hal ini, tanggung jawab pembayaran ganti rugi disgorgement yang melibatkan emiten dapat dikenakan kepada siapapun secara individu. Hal ini dapat menjadi kajian akademis bagi OJK selaku otoritas yang berwenang dalam mengesahkan RPOJK menjadi POJK tentang Disgorgement dan Disgorgement Fund di masa mendatang.

\section{DAFTAR PUSTAKA}

\section{Buku}

Anwar, Jusuf. Pasar Modal Sebagai Sarana Pembiayaan dan Investasi, Seri Pasar Modal I. (Bandung: Alumni, 2005)

Colley, John L. et.al. The McGraw-Hill Executive MBA Series: Corporate Governance. New York: The McGrawHill Companies, Inc, 2003.

Garner, Bryan A. Black Law's Dictionary, 8th edition, Thomson Reuters, 2004.

Gunawan, TJ. Konsep Pemidanaan Berbasis Nilai Kerugian Ekonomi, Cetakan Pertama, Yogyakarta: Genta, 2015.

Marzuki, Peter Mahmud. Penelitian Hukum. Jakarta: Kencana Prenada Media, 2013.
Muhammad, Abdul Kadir. Hukum dan Penelitian Hukum. Bandung: Citra Aditya Bakti, 2004.

Nasarudin, M. Irsan dkk. Aspek Hukum Pasar Modal Indonesia. Cetakan ke-7. Jakarta: Kencana Prenada, 2011

Rahadiyan, Inda. Tinjauan Umum tentang Pasar Modal di Indonesia: Pengawasan Pasar Modal Pasca Terbentuknya Otoritas Jasa Keuangan. Yogyakarta: UII Press, 2014.

Simanjuntak, Cornelius dan Natalie Mulia. Organ Perseroan Terbatas. Cetakan pertama, Jakarta: Sinar Grafika, 2009. 
United States Securities and Exchange Commission, Rules of Practice and Rules on Fair Fund and Disgorgement Plans, June 2018.

Widjaja, Gunawan. Seri Pengetahuan Pasar Modal. Cet. I Jakarta: Prenada Media, 2006.

\section{Jurnal}

Ais, Chatamarrasjid. "Fiduciary Duty" Sebagai Standar Para Direksi Dalam Melaksanakan Tugasnya", Jurnal Hukum dan Pembangunan No. 1, Tahun XXXI, (Januari-Maret 2001): 63.

Chang, Jacqueline K. "Kokesh v. SEC: The Demise of Disgorgement," North Carolina Banking Institute Vol.22, (2018).

E. Veronica, et. All. "Limitation Period for SEC Enforcement Matters". The Hedgefund Journal, (April-May 2017): 1.

Hanna, John. "The Securities Exchange Act of 1934". Carolina Law Review Vol. XXIII, Number I, (November 1934): 22. Imaniati, Neni Sri dan Diana Wiyanti, "Perlindungan Hukum Terhadap Investor dan Upaya BAPEPAM Dalam Mengatasi Pelanggaran dan Kejahatan Pasar". Mimbar Hukum No.4, Tahun XVI, (Oktober-Desember 2000): 341-357

Kusumawardani, Shinta Ikayani. "Pengaturan Kewenangan, dan Tanggung Jawab Direksi Dalam Perseroan Terbatas
(Studi Perbandingan Indonesia dan Australia)". Jurnal Magister Ilmu Hukum Udayana Vol.2, No.1, (2013): 7. Kurniawan. "Tanggung Jawab Direksi Dalam Kepailitan Perseroan Terbatas Berdasarkan Undang-Undang Perseroan Terbatas". Mimbar Hukum Vol. 24, No. 2, (Juni 2012): 187-375. . "Tanggung Jawab Pemegang Saham Perseroan Terbatas Menurut Hukum Positif'. Mimbar Hukum Vol.26, No. 1, (Februari 2014): 76-81

Kurniawan, Faisal dkk. "Unsur Kerugian Dalam Unjustified Erinchment untuk Mewujudkan Keadilan Korektif (Corrective Justice)". Yuridika Vol. 33, No.1, (Januari 2018): 23-24.

Mayasonda, Raysa dkk. "Kajian Terhadap Rencana Pengaturan Disgorgement Dalam Pasar Modal Indonesia”. Jurnal Cendekia Hukum Vol. 6, No. 1, (September 2020):8

Pulungan, Muhammad Hajoran. "Penegakan Hukum dalam Prinsip Keterbukaan Informasi di Pasar Modal". Jurnal Ilmu Hukum STIH Litigasi Vol.2, No. 1, (Februari 2018): 54

Putri,Uni Tsulasi. "Disgorgement as Remedial Action in Indonesia Capital Market Regime”. Jurnal Hukum Novelty Vol. 11, Issue 01, (2020): 4.

Salami, Rochani Urip. " Hukum Pasar Modal dan Tanggung Jawab Sosial". Jurnal Dinamika Hukum Vol.11, No.3, (September 2011): 441-442 
Sarwirini. "Implementasi Restorative Justice

Dalam Penegakan Hukum Pajak". Yuridika Vol. 29, No. 3, (SeptemberDesember 2014): 383.

Setianto, Verina Yuwono. "Pertanggung Jawaban Pribadi Direksi Pada Perseroan Terbatas yang Pailit". Mimbar Yustitia, Vol.1, No. 2, (Desember 2017): 211.

Simpson, Murray L. 'Investors' Civil Remedies Under The Federal Securities Laws", Depaul Law Review Vol.12, Issue I, Article 5, (1962):71.

Sjawie, Hasbullah F. "Tanggung Jawab Terbatas atas Tindakan Ultra Vires". Jurnal Hukum Prioris Vol. 6, No. 1, (2017): 12-32.

Subekti, Trusto. "Batasan Tanggung Jawab Direksi atas Kerugian Perusahaan". Jurnal Dinamika Hukum Vol.8, No.1, (2008).

Tambunan, Marhara Tua Mulyadi. “Tanggung Jawab Direksi Terhadap Pemegang Saham Beritikad Baik atas Pembelian Kembali Saham yang Batal Karena Hukum". Transparency, Jurnal Hukum Ekonomi, Vol. I, No. 1, (Feb-Mei 2013):1-8.

Ramelan, "Pertanggung Jawaban Korporasi dalam Hukum Pidana”. Jurnal Hukum Prioris, Vol. 1, No. 2, (Februari 2007): 118.

Weinrib, Ernest J. "Restitutionary Damages as Corrective Justice," Theoretical Inquiries in Law, Vol.1, (2001): 3.

\section{Skripsi/Tesis}

Mentari, Nikmah. "Pemberian Ganti Rugi Investor di Pasar Modal Melalui Disgorgement Fund". Tesis Magister Ilmu Hukum. Surabaya: Universitas Airlangga, 2019.

Isfandariyah, Siti Hapsah. "Tanggung Jawab Direksi atas Pelanggaran Fiduciary Duty dan Menyebabkan Perseroan Pailit". Tesis Magister Ilmu Hukum. Yogyakarta: Universitas Islam Indonesia, 2012.

Firmansyah, Dandy. "Tanggung Jawab Direksi atas Pengendalian Internal Dalam perseroan Terbuka”. Skripsi Sarjana Ilmu Hukum Fakultas Hukum. Jakarta: Universitas Indonesia, 2012.

\section{Peraturan Perundang-Undangan}

Undang-Undang Nomor 8 Tahun 1995 tentang Pasar Modal

Undang-Undang Nomor 40 Tahun 2007 tentang Perseroan Terbatas

Undang-Undang Nomor 21 Tahun 2011 tentang Otoritas Jasa Keuangan

Rancangan Peraturan Otoritas Jasa Keuangan Tentang Disgorgement dan Disgorgement Fund

\section{Naskah Internet}

Sugianto, Danang. "OJK akan Kumpulkan Uang Ganti Rugi dari 'Penjahat Bursa'”. https://finance.detik.com/bursa-danvalas/d-4433294/ojk-akan-kumpulkanuang-ganti-rugi-dari-penjahat-bursa. Diakses 28 februari 2019. 
Tari, Dwi Nicken. "OJK Wacanakan Pemberian Ganti Rugi Kepada Investor Akibat Tindak Pidana". https://market. bisnis.com/read/20190219/7/890532/ ojk-wacanakan-pemberian-ganti-rugikepada-investor-akibat-tindak-pidana-. Diakses 28 februari 2019.

Wareza, Monica. "Investor Makin Tenang, OJK Godok Aturan Rugi Transaksi Saham". https://www.cnbcindonesia. com/market/20190218180420-1756237/investor-makin-tenang-ojkgodok-aturan-rugi-transaksi-saham. diakses 28 Februari 2019.

OJK Kaji Dana Ganti Rugi Investasi Bagi Masyarakat, https://www.cnnindonesia. com/ekonomi/20190218194501-78370497/ojk-kaji-dana-ganti-rugiinvestasi-bagi-masyarakat diakses 28 februari 2019.

OJK. "Permintaan Tanggapan Masyarakat atas RPOJK tentang Disgorgement dan Disgorgement Fund di Bidang Pasar Modal”. https://www.ojk.go.id/ $\mathrm{id} /$ regulasi/otoritas-jasa-keuangan/ rancangan-regulasi/Pages/PermintaanTanggapan - Mas yarakat - atas RPOJK-tentang--Disgorgement-danDisgorgement-Fund-di-Bidang-PasarModal.aspx. diakses 28 februari 2019.
Investor Bulletin: How Victims of Securities Law Violations May Recover Money. https://www.sec.gov/oiea/investoralerts-bulletins/ib_recovermoney.html diakses 11 April 2019.

Collins Dictionary English, ill-gotten gains https://www.collinsdictionary.com/ dictionary/english/ill-gotten-gains diakses 11 Mei 2019.

Simamora, Novita Sari. "Regulasi Disgorgement dan Disgorgement Fund Bakal Rampung Tahun ini”. https://market.bisnis.com/ $\mathrm{read} / 20190329 / 7 / 906115 /$ regulasidisgorgement-disgorgment-fundbakal-rampung-tahun-ini. diakses 1 April 2019

"Investor Bulletin : How Victims of Securities Law Violation May Recover Money". www.sec.gov.org. diakses 13 Januari 2020.

"How investigation work, How Investigations Work". https://www.sec.gov/enforce/ how-investigations-work.html, diakses 10 Januari 2020.

"Tanggapan pengamat soal rencana OJK membentuk disgorgement fund". $<$ https://investasi.kontan.co.id/news/ tanggapan-pengamat-soal-rencanaojk-membentuk-disgorgement-fund $>$ diakses 18 April 2019 